\title{
EXPLORING THE RELATIONSHIP BETWEEN CEO CHARACTERISTICS AND PERFORMANCE
}

\author{
Josep GARCIA-BLANDON ${ }^{1,}{ }^{*}$, Josep M. ARGILÉS-BOSCH ${ }^{2}$, \\ Diego RAVENDA ${ }^{3}$ \\ ${ }^{1}$ IQS School of Management, Universitat Ramon Llull, Barcelona, Spain \\ ${ }^{2}$ Department of Accounting, Universitat de Barcelona, Barcelona, Spain \\ ${ }^{3}$ Department of Accounting, Toulouse Business School, Barcelona, Spain
}

Received 05 April 2018; accepted 30 April 2019

\begin{abstract}
This article examines the relationship between CEO characteristics and firm performance with a sample formed by the best performing CEOs in the world according to Harvard Business Review. The empirical analysis is based on descriptive statistics techniques and studies the universe of CEOs included in the 2016 ranking "The Best-Performing CEOs in the World" released by Harvard Business Review. Moreover, it addresses performance at various levels: financial performance, environmental, social and governance performance (ESG) and overall performance. The findings of the study show: 1) a strongly negative association between financial and ESG performance; 2) outsider CEOs outperform insider CEOs in overall performance; 3) CEOs with engineering degrees show significantly higher ESG performance; 4) CEOs with longer tenures in the firm present stronger financial performance though weaker ESG performance; and 5) the CEO's country of origin emerges as an important driver to explain the different types of performance. Results in this field contradict the conventional wisdom of Anglo-Saxon CEOs as the best performers CEOs.
\end{abstract}

Keywords: financial performance, ESG performance, cross-country differences, insider/outsider $\mathrm{CEO}$, educational background, CEO's age, CEO’s tenure.

JEL Classification: G30, L21, M12, M16.

\section{Introduction}

What drives CEO performance is a hot research topic in the literature and has been investigated from various perspectives. One of them addresses the role of CEO characteristics. Specifically, researchers have examined the role of the form of appointment of the CEO (internal or external) (Karaevli \& Zajac, 2013; Hoitash \& Mkrtchyan, 2018), academic background (Mintzberg, 2004; Gottesman \& Morey, 2010; Miller \& Xu, 2019), age (Hambrick \& Mason, 1984; Barker \& Mueller, 2002; Belenzon et al., 2019), tenure in the firm (Hambrick \&

${ }^{\star}$ Corresponding author. E-mail: josep.garcia@iqs.edu 
Fukutomi, 1991; Henderson, Miller, \& Hambrick, 2006), or the country of origin (Crossland \& Hambrick, 2011; Ioannou \& Serafeim, 2012; Boone, Lokshin, Guenter, \& Belderbos, 2019).

Until recently, the examination of performance was basically limited to financial performance, as measured by Tobin's Q, return on assets, return on equity or similar financial ratios. However, in parallel with the growing importance of corporate social responsibility issues, the measurement of performance exclusively through financial indicators is being considered as far too restrictive. As a result, the concept of Environmental, Social and Governance (ESG) performance is becoming increasingly popular, not only among researchers, but also for practitioners and market participants. While financial performance focuses on shareholders' wealth, ESG considers not only shareholders but also the environment (i.e., climate change, energy and water waste) as well as social responsibility issues (i.e., human rights, gender equality).

This study addresses the relationship between some characteristics of the CEO and performance. While scholars have extensively investigated this issue (Halikias \& Panayotopoulou, 2003; Prasad \& Junni, 2017), this study intends to complement previous related research and, therefore, to contribute to the literature. A common feature of most prior studies is the rather specific research focus. For example, they usually address a single issue (i.e., the tenure of the CEO, the academic background), a single country and/or industry, and a single metric of performance. Conversely, the approach followed in this paper is more general, as it undertakes a broad range of issues: form of appointment, academic background, age, tenure and country of origin. Moreover, the framework adopted is not country or industry specific but multinational and multi-industry. This allows to address, for example, the importance of the CEO's country of origin as a determinant of performance. Additionally, the analysis is not limited to financial performance but also considers ESG performance as well as overall performance. Finally, the empirical analysis is based on a sample formed by the best performing CEOs in the world according to the 2016 ranking released by Harvard Business Review (HBR, 2016a). This previously non-investigated sample seems as particularly suitable for the investigation of the relationship between CEO characteristics and performance. Therefore, this study allows to address to what extent the results of prior investigations on management performance hold when applied to this specific category of CEOs.

According to information on individual CEOs provided by the HBR ranking, the empirical analysis is conducted through the six research questions below:

1. Is there any significant relationship between financial and ESG performance?

2. Does the form of appointment of the CEO matter in terms of performance?

3. Does the educational background of the CEO matter in terms of performance?

4. Is there any significant relationship between CEO's age and performance?

5. Is there any significant relationship between CEO's tenure and performance?

6. Are there any implications of the CEO's country of origin on performance?

In anticipation of the results, it is observed a consistent and negative relationship between financial and ESG performance. It is also found that outsider CEOs generally outperform insider CEOs in terms of overall performance. As for the educational background, MBAs degrees are not associated with significantly different levels of overall performance, yet CEOs with engineering degrees tend to show higher ESG performance and, as a result, stronger 
overall performance. Whereas the age of the CEO does not seem to affect performance, long-tenured CEOs show stronger financial performance though weaker ESG performance. Finally, CEOs proceeding from the Anglo-Saxon region tend to show poorer ESG performance and, as a result, they also show weaker overall performance.

The remainder of the paper is organized as follows. The next section summarizes the related literature on each of the six research questions and develops up to eight hypotheses. Section three outlines the design of the empirical research, whereas section four presents and discusses the results. Finally, in the last section, the main conclusions, as well as the implications and limitations of the study, are drawn.

\section{Background and hypotheses}

\subsection{The relationship between financial and ESG performance}

The relationship between financial and ESG performance is controversial. Baumol (2016, p. 16) notes that: "Under the current laws and social pressures, there is little or no obligation for socially beneficial expenditure (i.e., philanthropic outlays) from private wealth accumulations". However, according to Eccles, Ioannou, and Serafeim (2014), the promoters of the "do well by doing good" rule ${ }^{1}$ (Godfrey, 2005; Porter \& Kramer, 2011) argue that by meeting the needs of other stakeholders, companies can directly create value for shareholders. Conversely, ignoring the interests of other stakeholders may erode shareholders' value, because of consumer boycotts, the inability to hire and retain talented people and by the costs imposed by government sanctions. Moreover, Preston and O'Bannon (1997) claim that the stakeholder theory favors a positive relationship between financial and social performance. Accordingly, firms which are unable to meet the expectations of non-shareholder stakeholders will be perceived by the market as riskier, leading to higher risk premiums and ultimately to lower financial performance (Cornell \& Shapiro, 1987). On the other hand, the trade-off hypothesis puts the focus on the costs associated with actions aiming to enhance ESG performance which will negatively impact financial performance (Friedman, 1970; Navarro, 1988). Following this view, sustainability would simply be another type of agency cost which results in the expropriation of shareholders' benefits by managers (Eccles et al., 2014). Companies that behave according to higher ESG standards face higher costs (for example, higher wages), and eventually will be eliminated by competitors who do not follow such high standards (Jensen, 2001).

The empirical evidence on the relationship between financial and ESG performance generally supports a positive relationship between them. While, in an early study, Vance (1975) finds that socially committed firms show poorer stock price behavior than the market, more recent research (Flammer, 2015) shows a positive relationship between financial and social performance. This is also the conclusion of various meta-analyses (Orlitzky, Schmidt, \& Rynes, 2003; Wang, Dou, \& Jia, 2016). Therefore, according to prior research, the first hypothesis of this research states:

\footnotetext{
1 "Socially responsible actions allow firms to create sustainable resource positions and relationships that lead to long-term competitive advantage" (Kaul \& Luo, 2018, p. 1650).
} 
Hypothesis \#1 (H1): ESG and financial performance will show positive and significant correlation.

\subsection{The form of appointment of the CEO: insiders versus outsiders}

The appointment of a CEO is a key organizational decision with important implications for the future of the firm (Datta \& Guthrie, 1994). Not surprisingly, it has concealed considerable attention among strategic management researchers. Nevertheless, researchers have been more concerned with the determinants of the decision to appoint an insider or an outsider CEO than with the potential impact of this decision on performance. According to Zhang and Rajagopalan (2003), the election of an insider CEO may present some potential advantages (i.e., capitalizes the insider's knowledge of the firm; minimizes the likelihood of a misfit between CEO and organization; promotes continuity and stability). However, the need for new perspective, skills or knowledge may justify the appointment of an outsider CEO. In the same vein, Hambrick and Mason (1984, p. 200) state that: "executives who have spent their entire careers in one organization can be assumed to have relatively limited perspectives". Conversely, outsider CEOs are expected to provide fresh knowledge, skills and perspective, prerequisites for managing change effectively (Finkelstein \& Hambrick, 1996). This is consistent with the fact that the rate of outside CEO succession among the largest international organizations more than doubled between 2007 and 2012 (Favaro, Karlsson, \& Neilson, 2013). These figures suggest an increasingly better perception of outsider CEOs. Therefore, although there is no consensus in the literature (Karaevli, 2007), the second hypothesis of this study states:

Hypothesis \#2 (H2): Outsider CEOs will show higher performance than insider CEOs.

\subsection{Educational background}

Should the educational background of the CEO have any impact on performance? Gottesman and Morey (2010) provide three possible explanations for a positive answer to this question. First, because the educational background affects the cognitive ability, which in turn affects performance; second, because education influences the behavior of the CEO, which in turn influences performance; and third, because education impacts the social capital of the CEO, which in turn influences performance. While it is impossible to capture the educational background just a few variables, the HBR ranking dataset provides two inputs of information for this background: MBAs degrees and engineering degrees.

CEOs holding MBAs degrees. In his celebrated book, Mintzberg (2004, p. 6) states: "Considered as education for management, conventional MBA programs train the wrong people in the wrong ways with the wrong consequences". The author labels most of MBA programs in the US and around the world as "conventional MBA programs". A similar view is provided by Hambrick and Mason (1984) who stress the focus of MBA programs on short-term performance at the expense of innovation and asset building. Accordingly, we should not expect stronger performance of CEOs with MBAs. This view is supported by Gottesman and Morey (2010) who find that CEOs with MBA degrees do not perform better than the rest and provide limited evidence that CEOs without MBAs show superior operating performance. Con- 
versely, Bertrand and Schoar (2003) conclude that CEOs with MBA degrees obtain return on assets on the order of one percent higher than non-MBA graduates. They also find that CEOs with MBAs are, in general, more aggressive managers and, consequently, we should assume, less concerned with sustainability issues. From the previous discussion, we expect lower ESG performance and not higher financial performance for CEOs with MBA degrees, and therefore, the third and fourth hypotheses are posed as follows:

Hypothesis \#3 (H3): Holding an MBA degree is not associated with higher financial performance.

Hypothesis \#4 (H4): Holding an MBA degree is associated with lower ESG performance.

CEOs holding an engineering degree. The impact of an engineering degree on performance may likely be driven by the sort of investments that CEOs who are engineers are expected to be more willing to undertake. According to Tyler and Steensma (1998), an educational background in science and engineering facilitates a more complete understanding of technology and innovation. Following this argument, Barker and Mueller (2002) argue that science and engineering background favors high levels of research and development spending.

The available empirical evidence supports this view. Specifically, Barker and Mueller (2002) and Gottesman and Morey (2010) observe that CEOs with technical educational backgrounds tend to spend more on research and development investment projects than other CEOs. Moreover, as sustainability often involves “(....) technically complex topics of energy conservation, climate change, biodiversity, and similar more natural science-based subjects" (Holliday, 2010, p. 535), CEOs with an engineering background are expected to show stronger performance in this field. Accordingly, we pose the fifth hypothesis of the study as follows:

Hypothesis \#5 (H5): Holding an engineering degree is associated with higher financial and ESG performance.

\subsection{Age}

As noted by Hambrick and Mason (1984), the available evidence shows a positive association between managerial youth and corporate growth. Moreover, older executives tend to be more conservative, and therefore, less willing to take risks. According to Barker and Mueller (2002), these findings are usually explained in terms of psychological reasons and incentives. Among the former group of factors, the authors point out lack of the necessary physical and mental stamina to carry out organizational changes and less ability for grasping new ideas and learning new behaviors. With regard the different incentives depending on age, older CEOs have less incentives to undertake risky investments, as for example, research and development projects. The reason is that they will have to personally bear the usual negative impact of these investment on current profitability, without benefiting of the investments payoffs which would likely take place in the long term. Supporting this view, Dechow and Sloan (1991) observe a decrease in research and development spending in the years immediately before the CEO leaving the company. Accordingly, we pose the sixth hypothesis of the study as follows:

Hypothesis \#6 (H6): There is a negative association between the age of the CEO and financial performance. 


\subsection{Tenure}

According to Hambrick and Fukutomi (1991), the different phases within an executive's tenure in a position results in distinct patterns of behavior and organizational performance. Therefore, as Miller (1991) point out, tenure may have both positive and negative effects on performance depending on the CEO's life cycle seasons. Following this view, Wu, Levitas, and Priem (2005) argue that during the earlier seasons, CEOs take up new initiatives and expand their knowledge and skills as tenure increases, thus improving firm performance. However, in the later seasons, CEOs become more strongly committed with their own view of the firm, myopically committed to obsolete paradigms, and tend to adapt less to the external environment (Miller, 1991; Levinthal \& March, 1993). Therefore, there are arguments supporting either a positive or negative relationship between tenure and financial performance. However, following our discussion of hypotheses $\mathrm{H} 2$ and H6, and taking into account that insider as well as older CEOs will generally show longer tenures, we expect a negative relationship between tenure and financial performance. Therefore, the seventh hypothesis states:

Hypothesis \#7 (H7): There is a negative association between the tenure of the CEO and financial performance.

\subsection{Country of origin}

The CEO's country of origin may impact performance through several ways. According to Crossland and Hambrick (2011), some country characteristics such as individualism, tolerance of uncertainty and ownership concentration are associated with the managerial discretion of the CEO. In turn, the ability of the CEO to impact firm's performance is also conditioned by managerial discretion. In the same line, Ioannou and Serafeim (2012) conclude that national formal institutions such as the political system and the labor, education and cultural systems are expected to affect corporate social performance. Overall, the country of origin may impact performance through: 1) national institutions such as political, labor, education and cultural systems (Ioannou \& Serafeim, 2012); 2) the influence on the values of the CEO (Bergson, Ore, \& Diver, 2008); and 3) managerial style (Culpan \& Kucukemiroglu, 1993). Therefore, we expect the country of origin of the CEO to have a significant influence on financial performance and, more importantly, on ESG performance. Accordingly, the last hypothesis of this study states:

Hypothesis \#8 (H8): CEOs from different countries will perform differently in terms of financial and ESG performance.

\section{Design of the study}

The empirical study is based on data publicly available at the HBR website (HBR, 2016b). The website provides individual information for each one of top $100 \mathrm{CEO}$ within the universe of the companies included in the S\&P Global 1200, ranked according to the overall rank variable (OVERALLRANK). The OVERALLRANK is constructed as a combination of three partial rankings: an overall financial ranking (TOTFINRANK) and two ESG rankings (SUSTAINRANK and CSRHUBRANK). TOTFINRANK is weighted at $80 \%$ while both ESG rankings are weighted at $10 \%$ each. The difficulties associated with the measurement of cor- 
porate social responsibility (Capelle-Blancard \& Petit, 2017) advocates the use of more than one ranking of ESG performance.

We assess the eight hypotheses of the study with the help of descriptive statistics techniques. It should be noted that a higher (lower) position in any performance ranking indicates lower (higher) performance. Table 1 shows how each specific hypothesis is addressed, whereas Table 2 provides information for the variables used in the study.

For the assessment of hypothesis $\mathrm{H} 1$, we use pairwise Pearson correlation coefficients between TOTFINRANK and both ESG rankings (SUSTAINRANK and CSRHUBRANK). The sign and level of statistical significance of these coefficients will provide support for or against the hypothesis. According to $\mathrm{H} 1$, we expect a positive and significant correlation of TOTFINRANK with both ESG rankings. Moreover, we also expect positive and significant correlation between both ESG rankings.

Table 1. Summary of the hypotheses and statistical analysis

\begin{tabular}{|l|l|}
\hline \multicolumn{1}{|c|}{ Hypotheses } & \multicolumn{1}{|c|}{ Statistical technique } \\
\hline $\begin{array}{l}\text { H1: ESG and financial performance will show positive } \\
\text { and significant correlation. }\end{array}$ & Pearson correlation coefficients \\
\hline $\begin{array}{l}\text { H2: Outsider CEOs will show higher performance } \\
\text { than insider CEOs }\end{array}$ & Mann-Whitney test \\
\hline $\begin{array}{l}\text { H3: Holding an MBA degree is not associated with } \\
\text { higher financial performance }\end{array}$ & Mann-Whitney test \\
\hline $\begin{array}{l}\text { H4: Holding an MBA degree is associated with lower } \\
\text { ESG performance }\end{array}$ & Mann-Whitney test \\
\hline $\begin{array}{l}\text { H5: Holding an engineering degree is associated with } \\
\text { higher financial and ESG performance }\end{array}$ & Mann-Whitney test \\
\hline $\begin{array}{l}\text { H6: There is a negative association between the age of } \\
\text { the CEO and financial performance. }\end{array}$ & $\begin{array}{l}\text { Pearson correlation, Kruskal-Wallis and } \\
\text { Mann-Whitney tests }\end{array}$ \\
\hline $\begin{array}{l}\text { H7: There is a negative association between the tenure } \\
\text { of the CEO and financial performance. }\end{array}$ & $\begin{array}{l}\text { Pearson correlation, Kruskal-Wallis and } \\
\text { Mann-Whitney tests }\end{array}$ \\
\hline $\begin{array}{l}\text { H8: CEOs from different countries will perform } \\
\text { differently in terms of financial and ESG performance }\end{array}$ & $\begin{array}{l}\text { Pearson correlation Kruskal-Wallis and } \\
\text { Mann-Whitney tests }\end{array}$ \\
\hline
\end{tabular}

Table 2. Variables, related proxies and relationship with the hypotheses

\begin{tabular}{|l|l|l|}
\hline \multicolumn{1}{|c|}{ Variable } & \multicolumn{1}{c|}{ Related proxy } & \multicolumn{1}{c|}{ Hypotheses } \\
\hline CEO's overall performance & OVERALLRANK & \\
\hline CEO's financial performance & TOTFINRANK & $\mathrm{H} 1$ \\
\hline CEO's ESG performance & SUSTAINRANK/CSRHUBRANK & $\mathrm{H} 1$ \\
\hline CEO's form of appointment & INSIDER/OUTSIDER & $\mathrm{H} 2$ \\
\hline CEO with a MBA degree & MBA & $\mathrm{H} 3$ and H4 \\
\hline CEO with an engineering degree & ENGIN & $\mathrm{H} 5$ \\
\hline CEO's age & AGE & $\mathrm{H} 6$ \\
\hline CEO's tenure & TENURE & $\mathrm{H} 7$ \\
\hline CEO's region of origin & REGION/COUNTRY & $\mathrm{H} 8$ \\
\hline
\end{tabular}


For hypothesis H2, we first split the original sample into two subsamples defined according to the form of appointment of the CEO (insider or outsider). Then, for all four performance rankings, we compute the median rank for each subsample and, finally, conduct the Mann-Whitney test of difference of medians to assess for significant differences between insider and outsider CEOs. According to hypothesis H2, we expect a significantly lower median rank for the subsample of outsider CEO in all four rankings.

For hypotheses H3-H5 we use the same procedure as with H2. Specifically, for $\mathrm{H} 3$ and $\mathrm{H} 4$ we split the original sample into two subsamples defined by whether or not the CEO holds an MBA degree. Then, we compute the median of each ranking for both subsamples, and finally conduct the Mann-Whitney test. According to hypothesis H3, we do not expect significant differences in financial performance across subsamples. However, following hypothesis $\mathrm{H} 4$ we expect a significantly higher median rank for the subsample of CEOs with MBAs on both metrics of ESG performance. Next, we follow the same procedure for the assessment of hypotheses $\mathrm{H} 5$, the only change being the substitution of the criterion of an MBA degree by an engineering degree to define subsamples. We expect significantly lower medians for financial and ESG (H5) rankings in the subsample of CEOs with engineering degrees.

The assessment of hypotheses H6 and H7 involves the use of three different statistical techniques: Pearson correlation coefficients, Kruskal-Wallis test and Mann-Whitney test. According to hypothesis H6, we should expect a positive and significant correlation between the age of the CEO and the position in the rank of financial performance. To conduct the Kruskal-Wallis test we split the original sample into three subsamples according to the age of the CEO (less than 58 years, between 58 and 63 and more than 63). The cut-off points to define subsamples are chosen with the aim of having subsamples of similar size. The KruskalWallis test allows to assess for significant differences in the performance rankings across age categories. In those rankings where the Kruskal-Wallis test indicates significant differences by age, we subsequently perform the Mann-Whitney test comparing each category with the rest of the sample to assess which age subsample performs better. For hypothesis H7 we proceed in a similar way, the only difference being that subsamples are defined according to the tenure of the CEO in the firm (less than 10 years, between 10 and 20 years and more than 20 years). Again, cut-off points are chosen to achieve subsamples of similar size.

Hypothesis H8 is first addressed grouping the countries by regions. Adapting LaPorta, Lopez-de-Silanes, Shleifer, and Vishny (1998) classification scheme, we consider three regions: Anglo-Saxon common law region (US, UK, Hong-Kong, Canada, Australia and Papua New Guinea), France civil-law region (France, Spain, Brazil, Mexico, Belgium, Netherlands and Argentina) and German-Scandinavian civil-law region (Germany, Denmark, Sweden, Japan, Taiwan and Switzerland). Subsequently, we conduct the Kruskal-Wallis test to look for significant differences in performance across regions. Finally, whenever significant differences are reported, we compute the Mann-Whitney test comparing each region with the rest to find out which region performs better. After this region-based analysis and, given the large number of CEOs from the US in the original sample, we conduct the Mann-Whitney test to examine whether CEOs from the US perform significantly different than the rest.

Every time we provide the median values of the rankings across subsamples of CEOs, we also provide the average values. However, the nature of the variables examined (ranks) does 
not allow the use of the $t$-test of differences of means, and therefore, only the results of the Mann-Whitney test are provided.

Table 3. Descriptive information for our sample

\begin{tabular}{|l|l|}
\hline \multicolumn{1}{|c|}{ Variable } & \multicolumn{1}{c|}{ Number of CEOs (or years when stated) } \\
\hline CEO's form of appointment & Internal (84); External (16) \\
\hline CEO with a MBA degree & Yes (24); No (76) \\
\hline $\begin{array}{l}\text { CEO with an engineering } \\
\text { degree }\end{array}$ & Yes (24); No (75); Non-available (1) \\
\hline CEO's age & Average (60 years); Median (60 years); Max. (88 years); Min. (44 years) \\
\hline CEO's tenure & Average (17 years); Median (15 years); Max. (63 years); Min. (3 years) \\
\hline CEO's region of origin & $\begin{array}{l}\text { Anglo-Saxon common law (62); France civil-law (22); } \\
\text { German-Scandinavian civil-law (16) }\end{array}$ \\
\hline
\end{tabular}

Table 3 displays some information for our sample of CEOs and provides some interesting results. First, most CEOs have been appointed internally. This seems to contradict Favaro et al. (2013) who reported that the rate of outside CEO succession among the largest international organizations increased from 14\% in 2007 to $29 \%$ in 2012. Moreover, there are the same number of CEOs with MBAs as with engineering degrees. The average and median age of the CEOs in our sample is 60 years, and tenures are generally rather long, with an average of 17 years. Finally, as expected, most CEOs in our sample belong to the Anglo-Saxon common law region (62\% of the sample and $43 \%$ from the US).

\section{Main results of the study}

\subsection{The relationship between financial and ESG performance}

Pearson correlation coefficients in Table 4 show that financial performance is negatively and significantly correlated with both rankings of ESG performance. These results indicate a clear trade-off between financial and ESG performance. Therefore, we find no support for hypothesis $\mathrm{H1}$, but rather the contrary. Table 4 also displays similar results for both rankings of ESG performance, which also show strong and positive correlation with each other.

Table 4. Pearson correlation coefficients for the rankings of performance

\begin{tabular}{|l|c|c|}
\hline & TOTFINRANK & SUSTAINRANK \\
\hline TOTFINRANK & 1.00 & \\
\hline SUSTAINRANK & $-0.61^{* * *}$ & 1.00 \\
\hline CSRHUBRANK & $-0.65^{* * *}$ & $0.79^{* * *}$ \\
\hline
\end{tabular}

*** indicates statistical significance at the $1 \%$ level.

Our findings support the view that the costs of implementing sustainability policies will eventually result in lower financial performance (Friedman, 1970; Navarro, 1988; Eccles et al., 
2014). Therefore, while most prior studies observe a direct relationship between ESG and financial performance (Orlitzky et al., 2003; Wang et al., 2016), our results indicate that this does not hold when we put the focus on the top performing CEOs.

\subsection{The form of appointment of the CEO: insiders versus outsiders}

Table 5 provides mean and median positions in the rankings for outsider and insider CEOs, as well as the results of the Mann-Whitney test to assess about the statistical significance of differences in positions across categories. The table shows lower median and mean positions (stronger performance) in all four rankings for outsider CEOs compared to insider CEOs. However, these differences are statistically significant only for the OVERALLRANK. It seems that, although outsider CEOs outperform insider CEOs in both financial and ESG performance, only when both forms of performance are simultaneously considered we are able to observe significant differences in the positions in the rankings. Therefore, these results support hypothesis $\mathrm{H} 2$ stating that outsider CEOs would be better performers and are consistent with the increasingly better perception of outsider CEOs as suggested by the rate of outside CEO succession among the largest international organizations (Favaro et al., 2013).

Table 5. Median (mean) positions in rankings for insider and outsider CEOs

\begin{tabular}{|l|c|c|c|c|}
\hline & OVERALLRANK & TOTFINRANK & SUSTAINRANK & CSRHUBRANK \\
\hline Outsider CEO & 28 & 51 & 227 & 254 \\
& $(37)$ & $(56)$ & $(316)$ & $(341)$ \\
\hline \multirow{2}{*}{ Insider CEO } & 54 & 65 & 362 & 407 \\
& $(53)$ & $(70)$ & $(355)$ & $(426)$ \\
\hline Mann-Whitney Test & $* *$ & & & \\
\hline
\end{tabular}

* indicates statistical significance at the $5 \%$ level.

\subsection{Educational background}

Table 6 (panel A) summarizes the results regarding the importance of the educational background as a driver of performance. As it can be seen, CEOs with MBA degrees present higher positions in the rankings compared with CEOs without MBAs, thus indicating weaker performance. However, as these differences are not statistically significant according to the Mann-Whitney test, we cannot conclude that MBA degrees are associated with lower performance. Therefore, results provide support for hypothesis H3 (CEOs with MBAs will not show stronger financial performance), though not for hypothesis $\mathrm{H} 4$ (MBAs will be associated with lower ESG performance). We should conclude that MBAs degrees are not associated with significantly different levels of performance, no matter which type of performance we refer to. The latter finding seems to put into question the view that CEOs with MBAs are more aggressive managers, less concerned with sustainability matters (Bertrand \& Schoar, 2003). This result may be explained by the fact that sustainability issues are becoming increasingly important in most MBA programs. 
Table 6. Median (mean) positions in rankings by educational background and age

Panel A. Educational background

\begin{tabular}{|c|c|c|c|c|}
\hline & OVERALLRANK & TOTFINRANK & SUSTAINRANK & CSRHUBRANK \\
\hline $\begin{array}{l}\text { CEOs with MBA } \\
\text { degrees }\end{array}$ & $\begin{array}{c}58 \\
(55)\end{array}$ & $\begin{array}{c}71 \\
(77)\end{array}$ & $\begin{array}{c}382 \\
(352)\end{array}$ & $\begin{array}{c}415 \\
(402)\end{array}$ \\
\hline $\begin{array}{l}\text { CEOs without MBA } \\
\text { degrees }\end{array}$ & $\begin{array}{c}47 \\
(49)\end{array}$ & $\begin{array}{c}54 \\
(65)\end{array}$ & $\begin{array}{c}338 \\
(347)\end{array}$ & $\begin{array}{c}394 \\
(415)\end{array}$ \\
\hline \multicolumn{5}{|l|}{ Mann-Whitney Test } \\
\hline $\begin{array}{l}\text { CEOs with } \\
\text { engineering degrees }\end{array}$ & $\begin{array}{c}33 \\
(38)\end{array}$ & $\begin{array}{c}72 \\
(65)\end{array}$ & $\begin{array}{l}236 \\
(259)\end{array}$ & $\begin{array}{c}326 \\
(384)\end{array}$ \\
\hline $\begin{array}{l}\text { CEOs without } \\
\text { engineering degrees }\end{array}$ & $\begin{array}{c}55 \\
(54)\end{array}$ & $\begin{array}{c}55 \\
(69)\end{array}$ & $\begin{array}{c}408 \\
(377)\end{array}$ & $\begin{array}{c}415 \\
(421)\end{array}$ \\
\hline Mann-Whitney test & $* *$ & & $* *$ & \\
\hline
\end{tabular}

Panel B: Age

\begin{tabular}{|l|c|c|c|c|}
\hline & OVERALLRANK & TOTFINRANK & SUSTAINRANK & CSRHUBRANK \\
\hline Less than 58 years & 53 & 67 & 333 & 317 \\
$(52)$ & $(72)$ & $(353)$ & $(389)$ \\
\hline $\begin{array}{l}\text { Between } 58 \text { and } \\
\text { 63 years }\end{array}$ & 53 & 70 & 302 & 400 \\
\hline More than 63 years & $(52)$ & $(72)$ & $(331)$ & $(401)$ \\
\hline Kruskal-Wallis test & & $(42$ & 382 & 464 \\
$(48)$ & & & \\
\hline
\end{tabular}

** indicates statistical significance at the $5 \%$ level.

On the contrary, when we examine the relationship between holding an engineering degree and performance, results indicate that CEOs with an engineering background tend to perform better than other CEOs. This result is observed in the OVERALLRANK as well as in both ESG rankings. However, holding an engineering degree is also associated with weaker financial performance as shown by the median values of TOTFINRANK. The Mann-Whitney test indicates that whereas differences in ESG (SUSTAINRANK) and overall performance (OVERALLRANK) are statistically significant, differences in financial performance are not. These results provide partial support for hypothesis H5 (engineering degrees are associated with stronger financial and ESG performance). Regarding financial performance, our results do not seem to support the findings of Gottesman and Morey (2010), that CEOs with degrees in technical fields spend significantly more on research and development investment projects. However, the fact that these types of investments usually have a negative short-term impact on financial performance may explain this unexpected result. Therefore, we conclude that CEOs with engineering background perform significantly better than other CEOs, and that this superior overall performance relies on stronger ESG performance.

It should be noted, however, that the fact that the educational background of CEOs is not homogeneous across sectors (i.e., CEOs with engineering backgrounds are more usual in the industry sector than in financial services companies, whereas the opposite situation holds for 
CEOs with MBAs) may have also influenced the reported relationships between educational background and performance. To further explore this issue, first we check whether CEOs with MBAs and with engineering degrees are homogeneously distributed between service firms and other firms. Results indicate that, as expected, MBAs degree are more frequent in service firms (32\%) than in other firms (22\%), whereas the contrary holds for engineering degrees ( $14 \%$ in service firms versus $27 \%$ in other firms). Subsequently, we have replicated the analysis but restricted to CEOs of service companies (22 CEOs in the HBR ranking). In this segmented analysis, the median position of CEOs with MBA degrees in the OVERALLRANK is 53 , whereas for CEOs without MAB degrees is 43 . It should be noted that, as it occurs in the analysis conducted with the whole sample displayed in Table 6 (panel A), differences in performance between CEOs with and without MBA degrees are not statistically significant at the usual levels. When we repeat the analysis restricted to service companies but using engineering degrees instead of MBAs, the median position of CEOs with engineering degrees in the OVERALLRANK is 36 , whereas for without this degree is 53 . Therefore, even in service companies, holding an MBA degree seems to be associated with lower overall performance whereas the contrary occurs for engineering degrees.

\subsection{Age}

We compute pairwise Pearson correlation coefficients between age and performance for each ranking. With the only exception of CSRHUBRANK $(0.17$, significant with $P$-value $<0.1)$, in all cases the coefficients are not significantly different from zero. This seems to anticipate an insignificant relationship between CEOs age and any performance metric.

Table 6 (panel B) provides CEOs mean and median positions in the rankings by age. In general, results do not seem to differ across subsamples of age. Focusing on OVERALL$R A N K$, the oldest CEOs appear to be the best performers, as they show the lowest mean and median values. This stronger overall performance seems to be built up on a better financial performance, as these CEOs also show the lowest ESG performance. However, the KruskalWallis test indicates that differences in performance across age categories are not statistically significant in any of the rankings. Accordingly, our results offer no support for hypothesis H6 (negative association between age and financial performance), and we should conclude that the age of the CEO does not seem to be a driver of performance. This unexpected result may be explained by the low variability of CEOs age in our sample of companies, which could not allow to capture adequately the age effect, as for example, in $85 \%$ of cases the age of the $\mathrm{CEO}$ is between 50 and 65 years.

\subsection{Tenure}

Pearson correlation coefficients between performance rankings and CEO's tenure show a strong and negative correlation between tenure and TOTFINRANK $(-0.40)$, indicating that financial performance increases with tenure. Conversely, we also see a strong positive correlation between tenure and both rankings of ESG performance ( 0.32 for SUSTAINRANK and 0.40 for CSRHUBRANK), showing that longer tenures are associated with lower performance. In all cases these coefficients are statistically significant at the standard levels. The opposite 
signs of the relationships of financial and ESG performance with tenure seem to cause the correlation between tenure and overal performance to be insignificant.

Table 7 displays median and mean positions in the rankings across categories of tenure for all four rankings. The table suggests strong positive association between tenure and financial performance. Specifically, the median position in the ranking of financial performance is 30 for CEOs with the longest tenures, 55 for CEOs with medium tenures and 100 for CEOs with the shortest tenures. For ESG performance rankings, we observe the opposite situation. Therefore, for the overall performance ranking, differences are not that big as for the financial ranking. However, CEOs with the longest tenure still show the strongest overall performance. The Kruskal-Wallis test indicates that differences in performance by categories of tenure are statistically significant for financial performance and for both rankings of ESG performance, but not for overall performance. Because results for financial and ESG performance have opposite signs, they tend to cancel-out in the overall performance rank. The results of the Mann-Whitney test strongly support this view, as CEOs with more than 20 years of tenure show significantly stronger financial performance and significantly lower ESG performance than other CEOs, in the latter case, no matter how ESG performance is measured. On the contrary, CEOs with tenures under 10 years show significantly stronger ESG performance (for both ranks of ESG performance), though significantly weaker financial performance. These results do not support hypothesis $\mathrm{H7}$ (negative association between the tenure and financial performance), but rather the contrary. Interestingly, our findings suggest that CEOs with a longer experience in the firm seem to be more focused on financial performance, while recently appointed CEOs are more concerned with sustainability issues. This view is consistent with the results for hypothesis $\mathrm{H} 2$ indicating that outsider CEOs (with shorter tenures) show stronger ESG performance.

Table 7. Median (mean) positions in rankings by tenure ${ }^{2}$

\begin{tabular}{|l|c|c|c|c|}
\hline & OVERALLRANK & TOTFINRANK & SUSTAINRANK & CSRHUBRANK \\
\hline Less than 10 years & $\begin{array}{c}51 \\
(49)\end{array}$ & $\begin{array}{c}100^{* * *} \\
(96)\end{array}$ & $\begin{array}{c}254^{* *} \\
(270)\end{array}$ & $\begin{array}{c}249^{* * *} \\
(276)\end{array}$ \\
\hline Between 10 and & 55 & 55 & 373 & 480 \\
20 years & $(53)$ & $(63)$ & $(377)$ & $(444)$ \\
\hline More than 20 & 44 & $30^{* * *}$ & $408^{*}$ & $544^{* * *}$ \\
years & $(48)$ & $(47)$ & $(386)$ & $(502)$ \\
\hline Kruskal-Wallis test & & $* * *$ & $*$ & $*$ \\
\hline
\end{tabular}

${ }^{\star},{ }^{* *}$ and ${ }^{* * *}$ indicates statistical significance at the $10 \%, 5 \%$ and $1 \%$ level, respectively.

\subsection{Country of origin}

First, we look for potential differences in performance between CEOs from different regions: Anglo-Saxon common-law (US, UK, Hong-Kong, Canada, Australia and Papua New Guinea), France civil-law (France, Spain, Brazil, Mexico, Belgium, Netherlands and Argentina)

\footnotetext{
${ }^{2}$ Whenever the Kruskal-Wallis test supports the existence of significant differences in performance by tenure, we conduct the Mann-Whitney test, comparing each specific category with the rest.
} 
and German-Scandinavian civil-law (Germany, Denmark, Sweden, Japan, Taiwan and Switzerland). Afterwards, we perform a similar analysis but comparing CEOs from the US with other CEOs. As in the former hypothesis, the first analysis starts with the Kruskal-Wallis test assessing for differences in performance by the region of origin of the CEO. Table 8 (panel A) displays the results of this analysis.

The Kruskal-Wallis test suggest significant differences in overall performance as well as in both ESG performance rakings across regions. Yet, the region of the CEO is not associated with different levels of financial performance. Morevoer, the examination of median values and the results of the Mann-Whitney test indicate that CEOs from the France civil-law region significantly outperform other CEOs in both ESG rankings (lower position in the rankings). Conversely, CEOs from the Anglo-Saxon common-law region significantly underperform other CEOs in both ESG rankings. A similar pattern is observed with regard the overall performance ranking, as CEOs from the France civil-law region significantly outperform the rest of CEOs, whereas CEOs from the Anglo-Saxon region show significantly lower performance. As for financial performance, CEOs from the German-Scandinavian civil-law region are the best performers, whereas CEOs from the France civil-law region are the worst performers. However, differences in financial performance are not statistically significant. These findings support the main conclusions of Van den Heuvel, Soeters, and Gössling (2014) that employees from continental European countries are more concerned about business conforming to ethical norms than with economic performance compared to enployees from English-speaking countries.

These results allow to draw several conclusions. First, the region of origin of the CEO is an important factor to explain ESG performance, but not to explain different levels of financial performance; second, CEOs from the France civil-law region tend to perform better than the rest, and base this superior overall performance on stronger ESG performance; and third, CEOs from the Anglo-Saxon common-law region tend to perform worse than the rest, due to a poorer ESG performance. Overall, results provide partial support for hypothesis $\mathrm{H} 8$, as the country of origin of the CEO is important for ESG performance, but not for financial performance. These findings suggest that country differences are important for sustainability issues though not for financial performance. This seems rather plausible, as we expect national differences with regard formal institutions and some specific country characteristics (which are regarded as main drivers of sustainability) to be more important than national differences regarding financial issues.

Finally, we provide the results of the analysis at the country level. Table 8 (panel B) compares CEOs from the US with other CEOs. As most CEOs from the Anglo-Saxon region are in fact from the US, the results of this analysis should not differ much from those displayed in Table 8 (panel A). However, we observe some interesting differences. Specifically, CEOs from the US show significant stronger financial performance than CEOs from other countries, and also significant weaker ESG performance, in the latter case no matter how ESG performance is measured. Both contradictory effects cancel-out in the overall performance ranking and, therefore, we do not observe significantly different overall performance between US and non-US CEOs. Although US CEOs show a somewhat weaker overall performance than the rest (slightly higher median and mean positions in the rankings), these differences are not statistically significant. 
Table 8. The importance of the CEO's country of origin

Panel A: Median (mean) positions in rankings by region ${ }^{3}$

\begin{tabular}{|l|c|c|c|c|}
\hline & OVERALLRANK & TOTFINRANK & SUSTAINRANK & CSRHUBRANK \\
\hline $\begin{array}{l}\text { Anglo-Saxon } \\
\text { common-law }\end{array}$ & $\begin{array}{c}56^{* *} \\
(56)\end{array}$ & $\begin{array}{c}54 \\
(64)\end{array}$ & $\begin{array}{c}416^{* * *} \\
(407)\end{array}$ & $\begin{array}{c}452^{* *} \\
(459)\end{array}$ \\
\hline France civil-law & $\begin{array}{c}29^{* * *} \\
(36)\end{array}$ & $\begin{array}{c}76 \\
(84)\end{array}$ & $\begin{array}{c}197^{* * *} \\
(204)\end{array}$ & $\begin{array}{c}161^{* * *} \\
(262)\end{array}$ \\
\hline $\begin{array}{l}\text { German- } \\
\begin{array}{l}\text { Scandinavian } \\
\text { civil-law }\end{array}\end{array}$ & $\begin{array}{c}44 \\
(49)\end{array}$ & $\begin{array}{c}47 \\
(62)\end{array}$ & $\begin{array}{c}290 \\
(320)\end{array}$ & $\begin{array}{c}452 \\
(438)\end{array}$ \\
\hline $\begin{array}{l}\text { Kruskal-Wallis } \\
\text { test }\end{array}$ & $* *$ & & $* * *$ & $* * *$ \\
\hline
\end{tabular}

Panel B: Median (mean) positions in rankings for US and non-US CEOs

\begin{tabular}{|l|c|c|c|c|}
\hline & OVERALLRANK & TOTFINRANK & SUSTAINRANK & CSRHUBRANK \\
\hline US CEOs & 51 & 41 & 408 & 491 \\
& $(52)$ & $(55)$ & $(423)$ & $(499)$ \\
\hline Non-US CEOs & 48 & 76 & 248 & 294 \\
$(49)$ & $(78)$ & $(293)$ & $(346)$ \\
\hline $\begin{array}{l}\text { Mann-Whitney } \\
\text { test }\end{array}$ & & $* *$ & $* * *$ & $* * *$ \\
\hline
\end{tabular}

${ }_{* *}$ and ${ }^{* * *}$ indicates statistical significance at the $5 \%$ and $1 \%$ level, respectively.

\section{Conclusions}

The results of this research allow to draw several interesting conclusions. First, it is observed a clear trade-off between financial and ESG performance, as higher levels of financial performance are strongly associated with weaker ESG performance. Regarding the form of appointment, outsider CEOs tend to perform better than insider CEOs. Focusing on CEOs' educational background, MBA degrees are associated with poorer financial, ESG and overall performance, however results are not statistically significant. Conversely, CEOs with engineering degrees tend to show significantly higher ESG performance and, as a result, stronger overall performance. Additionally, while the age of the CEO does not seem to be a driver of performance, CEO's tenure in the firm appears to be an important factor. Specifically, longtenured CEOs show stronger financial performance, though weaker ESG performance. Nevertheless, the most interesting results of the paper are observed in the cross-region and crosscountry analyses. In this regard, CEOs proceeding from the Anglo-Saxon region perform significantly weaker than other CEOs in both ESG rankings and, as a result, show poorer overall performance. Conversely, CEOs from the France civil-law region show stronger ESG performance and, consequently, better overall performance. Finally, focusing specifically on CEOs from the US, the weaker ESG performance is offset by stronger financial performance.

\footnotetext{
${ }^{3}$ Whenever the Kruskal-Wallis test supports the existence of significant differences in performance by region, we conduct the Mann-Whitney test, comparing each region with the rest.
} 
These results may have some meaningful implications. First, some of the general conclusions regarding the importance of CEOs characteristics as drivers of firm performance do not seem to hold when the analysis focuses on the the top performer's CEOs. Therefore, the investigation of the causes behind these differences provides an interesting line of research. At a more practical level, the findings of this study contradict the conventional wisdom of a supposedly stronger performance of Anglo-Saxon CEOs compared with CEOs from other regions. Moreover, the relatively poorer performance of Anglo-Saxon CEOs in sustainability may compromise future overall performance, as sustainability issues are becoming increasingly important.

This study is subject to several limitations. First, the broad research focus adopted does not allow to conduct in-depth analyses of any of the issues investigated. Moreover, the empirical analysis based on descriptive statistics techniques does not permit to refer to causality between any of the CEOs characteristics examined in the study and performance. Therefore, a first extension of this exploratory research would be to address the issues investigated here with sounder econometric tools, such as regression analysis. Additionally, whereas this study investigates the relationship between CEO's characteristics and the firm's position in the rankings of performance, it would be interesting to address, using multivariate logistic analysis, how these characteristics may affect the likelihood that a firm is included as a one of the best performers in the world.

\section{Funding}

This work has received no funding.

\section{Author contributions}

Josep Garcia-Blandon conceived the study and was responsible for the design of the methodology. Josep M. Argilés-Bosch was responsible for data collection and interpretation, whereas Diego Ravenda conducted the statistical analysis.

\section{Disclosure statement}

The authors declare no competing financial, professional, or personal interests from other parties.

\section{References}

Barker, V., \& Mueller, G. (2002). CEO characteristics and firm R\&D spending. Management Science, 48(6), 782-801. https://doi.org/10.1287/mnsc.48.6.782.187

Baumol, W. J. (2016). On the appropriate social responsibilities of successful entrepreneurs. Business \& Society, 55(1), 14-22. https://doi.org/10.1177/0007650314523087

Belenzon, S., Shamshur, A., \& Zarutskie, R. (2019). CEO's age and the performance of closely held firms. Strategic Management Journal (in press). https://doi.org/10.1002/smj.3003 
Bergson, Y., Ore, S., \& Diver, T. (2008). CEO values, organizational culture and firm outcomes. Journal of Organizational Behavior, 29(5), 615-633. https://doi.org/10.1002/job.499

Bertrand, M., \& Schoar, A. (2003). Managing with style: The effect of managers on firm policies. Quarterly Journal of Economics, 118(4), 1169-1208. https://doi.org/10.1162/003355303322552775

Boone, C., Lokshin, B., Guenter, H., \& Belderbos, R. (2019). Top management team nationality diversity, corporate entrepreneurship, and innovation in multinational firms. Strategic Management Journal, 40(2), 277-302. https://doi.org/10.1002/smj.2976

Capelle-Blancard, G., \& Petit, A. (2017). The weighting of CSR dimensions: one size does not fit all. Business \& Society, 56(6), 919-943. https://doi.org/10.1177/0007650315620118

Cornell, B., \& Shapiro, A. C. (1987). Corporate stakeholders and corporate finance. Financial Management, 16(1), 5-14. https://doi.org/10.2307/3665543

Crossland, C., \& Hambrick, D. C. (2011). Differences in managerial discretion across countries: how nation-level institutions affect the degree to which CEOs matter. Strategic Management Journal, 32(8), 797-819. https://doi.org/10.1002/smj.913

Culpan, R., \& Kucukemiroglu, O. (1993). A comparison of US and Japanese management styles and unit effectiveness. Management International Review, 33(1), 27-42. Retrieved from https://www. jstor.org/stable/40228139

Datta, D. K., \& Guthrie, J. P. (1994). Executive succession: Organizational antecedents of CEO characteristics. Strategic Management Journal, 15(7), 569-577. https://doi.org/10.1002/smj.4250150706

Eccles, R. G., Ioannou, I., \& Serafeim, G. (2014). The impact of corporate sustainability on organizational processes and performance. Management Science, 60(11), 2835-2857. https://doi.org/10.1287/mnsc.2014.1984

Dechow, P. M., \& Sloan, R. G. (1991). Executive incentives and the horizon problem: An empirical investigation. Journal of Accounting and Economics, 14(1), 51-89. https://doi.org/10.1016/0167-7187(91)90058-S

Favaro, K., Karlsson, P., \& Neilson, G. (2013). Portrait of the incoming class. Booz \& Co. Retrieved from http://www.strategy-business.com/article/00184?gko=235be

Finkelstein, S., \& Hambrick, D. (1996). Strategic leadership: Top executives and their effects on organizations. Minneapolis: West Publishing.

Flammer, C. (2015). Does corporate social responsibility lead to superior financial performance? A regression discontinuity approach. Management Science, 61(11), 2549-2568. https://doi.org/10.1287/mnsc.2014.2038

Friedman, M. (1970). The social responsibility of business is to increase its profits. New York Times Magazine, September 13, 32-33.

Godfrey, P. C. (2005). The relationship between corporate philanthropy and shareholder wealth: A risk management perspective. Academy of Management Review, 30(4), 777-798. https://doi.org/10.5465/amr.2005.18378878

Gottesman, A. A., \& Morey, M. R. (2010). CEO educational background and firm financial performance. Journal of Applied Finance, 2, 70-82. Retrieved from https://ssrn.com/abstract=2693079

Halikias, J., \& Panayotopoulou, L. (2003). Chief executive personality and export involvement. Management Decision, 41(4), 340-349. https://doi.org/10.1108/00251740310468072

Hambrick, D. C., \& Fukutomi, G. D. (1991). The seasons of a CEO's tenure. Academy of Management Review, 16(4), 719-742. https://doi.org/10.5465/amr.1991.4279621

Hambrick, D. C., \& Mason, P. A. (1984). Upper echelons: The organization as a reflection of its top managers. Academy of Management Review, 9(2), 193-206. https://doi.org/10.5465/amr.1984.4277628

Harvard Business Review (staff) (HBR). (2016a). The best-performing CEOs in the world. Harvard Business Review (November), 41-57. 
Harvard Business Review (HBR). (2016b). How we calculated the ranking. Retrieved from https://hbr. org/2016/11/the-best-performing-ceos-in-the-world

Henderson, A. D., Miller, D., \& Hambrick, D. C. (2006). How quickly do CEOs become obsolete? Industry dynamism, CEO tenure, and company performance. Strategic Management Journal, 27(5), 447-460. https://doi.org/10.1002/smj.524

Hoitash, U., \& Mkrtchyan, A. (2018). Recruiting the CEO from the board: Determinants and consequences. Journal of Financial and Quantitative Analysis, 53(3), 1261-1295. https://doi.org/10.1017/S002210901800011X

Holliday, S. (2010). An interview with Chad Holliday, (former) CEO \& chairman, DuPont the relationship between sustainability education and business. Academy of Management Learning \& Education, 9(3), 532-541. https://doi.org/10.5465/amle.9.3.zqr532

Ioannou, I., \& Serafeim, G. (2012). What drives corporate social performance? The role of nation-level institutions. Journal of International Business Studies, 43(9), 834-864.

https://doi.org/10.1057/jibs.2012.26

Jensen, M. C. (2001). Value maximization, stakeholder theory, and the corporate objective function. Journal of Applied Corporate Finance, 14(3), 8-21. https://doi.org/10.1111/j.1745-6622.2001.tb00434.x

Karaevli, A. (2007). Performance consequences of new CEO "Outsiderness": Moderating effects of pre-and post-succession contexts. Strategic Management Journal, 28(7), 681-706. https://doi.org/10.1002/smj.589

Karaevli, A., \& Zajac, E. J. (2013). When do outsider CEOs generate strategic change? The enabling role of corporate stability. Journal of Management Studies, 50(7), 1267-1294. https://doi.org/10.1111/joms.12046

Kaul, A., \& Luo, J. (2018). An economic case for CSR: The comparative efficiency of for-profit firms in meeting consumer demand for social goods. Strategic Management Journal, 39(6), 1650-1677. https://doi.org/10.1002/smj.2705

LaPorta, R., Lopez-de-Silanes, F., Shleifer, A., \& Vishny, R. W. (1998). Law and finance. Journal of Political Economy, 106(6), 1113-1155. https://doi.org/10.1086/250042

Levinthal, D. A., \& March, J. G. (1993). The myopia of learning. Strategic Management Journal, 14(2), 95-112. https://doi.org/10.1002/smj.4250141009

Miller, D. (1991). Stale in the saddle: CEO tenure and the match between organization and environment. Management Science, 37(1), 35-52. https://doi.org/10.1287/mnsc.37.1.34

Miller, D., \& Xu, X. (2019). MBA CEOs, short-term management and performance. Journal of Business Ethics, 154(2), 285-300. https://doi.org/10.1007/s10551-017-3450-5

Mintzberg, H. (2004). Managers not MBAs: A hard look at the soft practice of managing and management development. San Francisco: Berrett-Koehler.

Navarro, P. (1988). Why do corporations give to charity? Journal of Business, 61(1), 65-93. https://doi.org/10.1086/296420

Orlitzky, M., Schmidt, F. L., \& Rynes, S. L. (2003). Corporate social and financial performance: A meta-analysis. Organization Studies, 24(3), 403-441. https://doi.org/10.1177/0170840603024003910

Porter, M., \& Kramer, M. (2011). Creating shared value. Harvard Business Review, 89(1/2), 62-77.

Prasad, B., \& Junni, P. (2017). A contingency model of CEO characteristics and firm innovativeness: The moderating role of organizational size. Management Decision, 55(1), 156-177. https://doi.org/10.1108/MD-02-2016-0071

Preston, L. E., \& O'Bannon, D. P. (1997). The corporate social-financial performance relationship: A typology and analysis. Business \& Society, 36(4), 419-429. https://doi.org/10.1177/000765039703600406 
Tyler, B. B., \& Steensma, H. K. (1998). The effects of executives' experiences and perceptions on their assessment of potential technological alliances. Strategic Management Journal, 19(10), 939-965. https://doi.org/10.1002/(SICI)1097-0266(199810)19:10<939::AID-SMJ978>3.0.CO;2-Z

Vance, S. C. (1975). Are socially responsible corporations good investment risks? Management Review, 64(8), 19-24.

Van den Heuvel, G., Soeters, J., \& Gössling, T. (2014). Global business, global responsibilities: Corporate social responsibility orientations within a multinational bank. Business \& Society, 53(3), 378-413. https://doi.org/10.1177/0007650311424724

Wang, Q., Dou, J., \& Jia, S. (2016). A meta-analytic review of corporate social responsibility and corporate financial performance: The moderating effect of contextual factors. Business \& Society, 55(8), 1083-1121. https://doi.org/10.1177/0007650315584317

Wu, S., Levitas, E., \& Priem, R. L. (2005). CEO tenure and company invention under differing levels of technological dynamism. Academy of Management Journal, 48(5), 859-873. https://doi.org/10.5465/amj.2005.18803927

Zhang, Y., \& Rajagopalan, N. (2003). Explaining new CEO origin: Firm versus industry antecedents. Academy of Management Journal, 46(3), 327-338. https://doi.org/10.5465/30040626 